\title{
Protection of Spiral Ganglion Neurons from Degeneration Using Small-Molecule TrkB Receptor Agonists
}

\author{
Qing Yu, ${ }^{1,3}$ Qing Chang, ${ }^{3}$ Xia Liu, ${ }^{5}$ Yunfeng Wang, ${ }^{2}$ Huawei Li, ${ }^{2}$ Shusheng Gong, ${ }^{1}$ Keqiang Ye, ${ }^{5}$ and Xi Lin ${ }^{3,4}$ \\ ${ }^{1}$ Department of Otolaryngology-Head and Neck Surgery, Beijing Tongren Hospital, Capital Medical University, Beijing, China 100730, ${ }^{2}$ Department of \\ Otolaryngology, Eye and Ear, Nose and Throat Hospital, Shanghai Fudan University, Shanghai, China 200031, and Departments of ${ }^{3}$ Otolaryngology, ${ }^{4}$ Cell \\ Biology, and ${ }^{P}$ athology and Laboratory Medicine, Emory University School of Medicine, Atlanta, Georgia 30322-3030
}

Neurotrophins (NTs) play essential roles in the development and survival of neurons in PNS and CNS. In the cochlea, NTs [e.g., NT-3, brain-derived neurotrophic factor (BDNF)] are required for the survival of spiral ganglion neurons (SGNs). Preservation of SGNs in the cochlea of patients suffering sensorineural deafness caused by loss of hair cells is needed for the optimal performance of the cochlear implant. Directly applying exogenous BDNF into the cochlea prevents secondary degeneration of SGNs when hair cells are lost. However, a common translational barrier for in vivo applications of BDNF is the poor pharmacokinetics, which severely limits the efficacy. Here we report that 7,8-dihydroxyflavone and 7,8,3'-trihydroxyflavone, both small-molecule agonists of tyrosine receptor kinase $\mathrm{B}$ (TrkB), promoted SGN survival with high potency both in vitro and in vivo. These compounds increased the phosphorylated TrkB and downstream MAPK and protected the SGNs in a TrkB-dependent manner. Their applications in the bulla of conditional connexin26 null mice offered significant protection for SGN survival. The function of survived SGNs was assessed by measuring evoked action potentials (APs) in vitro and electrically evoked auditory brainstem response (eABR) thresholds in vivo. APs were reliably evoked in cultured single SGNs treated with the compounds. In addition, eABR thresholds measured from the treated cochleae were significantly lower than untreated controls. Our findings suggest that these novel small-molecule TrkB agonists are promising in vivo therapeutic agents for preventing degeneration of SGNs.

\section{Introduction}

Most sensorineural hearing loss cases are caused by hair cell loss, which results in secondary degeneration of spiral ganglion neurons (SGNs) that normally innervate the organ of Corti before hair cell degeneration in many animal models (Ylikoski et al., 1993). Because cochlear implants rely on SGNs for transmitting signals to the central auditory centers, loss of the neurons reduces the benefit of implanted devices and could result in poor performance if the SGN survival is substantially below a functioning threshold (Clopton et al., 1980; Incesulu and Nadol, 1998). Neurotrophins (NTs) [e.g., brain-derived neurotrophic factor (BDNF) and NT-3] play essential roles in cochlear development (Farinas et al., 1994; Lefebvre et al., 1994; Ernfors et al., 1995). NT-3 shows significant long-term cochlear expression, whereas the receptors for both NTs are expressed into the adult stage

\footnotetext{
Received Feb. 25, 2013; revised June 10, 2013; accepted June 27, 2013.

Author contributions: Q.Y., K.Y., and X. Lin designed research; Q.Y., Q.C., X. Liu, Y.W., H.L., and X. Lin performed research; X. Liu, S.G., and K.Y. contributed unpublished reagents/analytic tools; Q.Y., Q.C., Y.W., H.L., S.G., K.Y., and X. Lin analyzed data; Q.Y., Q.C., K.Y., and X. Lin wrote the paper.

This study was supported by Major State Basic Research Development Program of China Grant 2011 CB504503 (S.G.), National Nature Science Foundation of China Grants 81100721 (Y.W.) and 30728029 (H.L.), National Institute on Deafness and Other Communication Disorders Grants R01 DC010204 and R01 DC006483 (X. Lin), and National Institutes of Health Grant R01 DC010204 (K.Y.). We thank Anne Lin for proofreading the final version of this manuscript.

The authors declare no competing financial interests.

Correspondence should be addressed to Drs. Xi Lin or Keqiang Ye, Emory University School of Medicine, Whitehead Building, Room 534, Atlanta, GA 30322. E-mail: xlin2@emory.edu; kye@emory.edu.

DOI:10.1523/JNEUROSCI.0854-13.2013

Copyright $\odot 2013$ the authors $\quad 0270-6474 / 13 / 3313042-11 \$ 15.00 / 0$
}

(Fritzsch et al., 1999; Kawamoto et al., 2001; Rubel and Fritzsch, 2002). Exogenous applications of BDNF directly into the cochlea rescue SGNs from degeneration in animal models in which degeneration of SGNs is caused by hair cell loss in adult animals after ototoxic insults (Staecker et al., 1996; Miller et al., 1997). However, the short plasma half-life and poor pharmacokinetics of BDNF greatly reduces its efficacy in vivo. Direct uses of BDNF have generated poor results in clinical trials (Saragovi and Gehring, 2000; Gillespie and Shepherd, 2005).

Recently, a number of small-molecule tyrosine receptor kinase B (TrkB) receptor agonists have been developed (Jang et al., 2010; Liu et al., 2010). These compounds readily crossed the blood-brain barrier and activate TrkB receptors in neurons with a half-effective concentration $\left(\mathrm{EC}_{50}\right)$ below $50 \mathrm{~nm}$ (Jang et al., 2010). 7,8-Dihydroxyflavone (7,8-DHF) was tested in a number of neurodegenerative animal models and show promising results (Blugeot et al., 2011; Johnson et al., 2012; Devi and Ohno, 2012). However, the effect of 7,8-DHF has not been examined for auditory neuroprotection. In addition, more potent $7,8-\mathrm{DHF}$ analog with better in vivo pharmacokinetics has also been developed. Based on extensive structural-activity relationship studies, a new compound, 7,8,3' -trihydroxyflavone (7,8,3'-THF), was identified. The new compound at least doubled the potency of 7,8-DHF in stimulating TrkB phosphorylation (Liu et al., 2010) and demonstrated some promising effect in protecting the SGNs (Yu et al., 2012). In this study, we conducted a thorough investigation for the neuroprotective effects of 7,8,3'-THF and 7,8-DHF, using both organotypic cultures of mouse cochlea and an in vivo model 
of degeneration of the peripheral auditory SGNs. Our in vivo studies used the conditional connexin26 (cCx26) knock-out mice (Wang et al., 2009). The secondary degeneration of SGNs in this line of genetically modified mice has been characterized in studies of the most common form of prelingual non-syndromic deafness in humans (Sun et al., 2009; Wang et al., 2009). We found that these small-molecule compounds phosphorylated the TrkB receptors as well as key molecules of downstream TrkB signaling and protected SGNs in a TrkB-dependent manner. The survival of SGNs was enhanced by both compounds with high potency in vitro and in vivo. The excitability of the SGNs rescued by these small-molecule TrkB agonists was also confirmed by both patch-clamp and eABR recordings. These results raise the hope of overcoming a major hurdle of drug delivery for the translational uses of the BDNF in auditory neuroprotection to benefit patients.

\section{Materials and Methods}

In vitro assays performed with the organotypic cochlear cultures. Animal use protocols in this study were approved by the Emory Institutional Animal Care and Use Committee. C57BL/6 (Charles River) and $\operatorname{TrkB}^{\mathrm{F} 616 \mathrm{~A}}$ (Jang et al., 2010) mice (either sex) were used to obtain cochlear tissues used in the cultures. We only used the segment isolated from the middle cochlear turn to ensure consistency. Cochleae from postnatal day 1 (P1) or P2 were dissected in ice-cold HBSS (Invitrogen). Detailed tissue dissection procedures were given in our published papers (Chang et al., 2008). The cochlear explants were cultured on glass coverslips prepared by coating with $500 \mu \mathrm{g} / \mathrm{ml}$ poly-D-lysine (Invitrogen) and $50 \mu \mathrm{g} / \mathrm{ml}$ laminin (Invitrogen) dissolved in HBSS for $2 \mathrm{~h}$ at $37^{\circ} \mathrm{C}$. A defined serum-free culture medium, which contained DMEM (SigmaAldrich), $10 \mu \mathrm{l} / \mathrm{ml} \mathrm{N} 2$ supplement (Invitrogen), 25 mм HEPES (SigmaAldrich), $6 \mathrm{mg} / \mathrm{ml}$ glucose, and $1 \mathrm{~mm}$ gentamicin (Sigma-Aldrich), were used. The cultures were maintained at $37^{\circ} \mathrm{C}$ in a $6.5 \% \mathrm{CO}_{2}$ incubator, and culture medium was replaced every $24 \mathrm{~h}$. Samples cultured for $72 \mathrm{~h}$ were used in the immunoassays. In different culture experiments, $100 \mathrm{ng} / \mathrm{ml}$ BDNF (Invitrogen), $300 \mathrm{~nm} 7,8,3^{\prime}$ - THF or 7,8-DHF (purity $>99 \%$; Indofine Chemical Company) was added as indicated in text.

The detailed immunolabeling protocol was given previously in our published papers (Sun et al., 2005). Briefly, samples were first incubated in primary antibody $(1: 400)$ at $4^{\circ} \mathrm{C}$ overnight. A mouse monoclonal antibody against class III $\beta$-tubulin (TUJ1; catalog \#MMS-435P; Covance) was used to label SGNs in cultures. Processed samples were mounted in an antifade solution (Fluoromount-G; Southern Biotechnology Associates), which also contained DAPI to label cell nuclei. Fluorescent images were acquired by a confocal microscope (Zeiss LSM; Carl Zeiss) and analyzed using NIH Image J software package (http://rsbweb.nih.gov/ij/features.html).

In Western blotting, we used a total of 24 cultured cochleae. These cultures were divided into four groups ( $n=6$ in each group) by their treatment (30 min) with BDNF (100 mg/ml), 7,8-DHF (300 nM), 7,8,3'THF (300 nM), or defined medium only with no supplement. The cochlear tissues in the four groups were rapidly collected into an Eppendorf tube and snap frozen in dry ice. Details of the Western blot protocol can be found in our previously published work (Ahmad et al., 2007). The bands of TrkB, phosphorylated TrkB (p-TrkB), Erk, and p-Erk were detected on the same membrane using antibodies against TrkB (catalog \#4603S, 1:1000; Cell Signaling Technology), p-TrkB (catalog \#sc135645, 1:200; Santa Cruz Biotechnology), Erk1/2 (catalog \#9102, 1:1000; Cell Signaling Technologies), and p-Erk1/2 (catalog \#9106S, 1:1000; Cell Signaling Technologies). Secondary antibodies were goat anti-rabbit (1: 3000 ) or anti-mouse (1:3000) IgG conjugated to the HRP (Bio-Rad).

In vivo delivery of the small-molecule TrkB agonist and morphological evaluations of the effect. cCx26 null mice younger than P2 (either sex) were cryo-anesthetized by placing the pups on ice for $3 \mathrm{~min}$. We used a retro-auricular approach to expose the tympanic membrane and tympanic ring. The stapedial artery and round window niche was exposed, and a small absorbable gelatin sponge $\left(2-3 \mathrm{~mm}^{3}\right.$; Gelfoam; catalog \#59-
9863; Pfizer) soaked with $15 \mu \mathrm{l}$ of 7,8,3' -THF (200 $\mu \mathrm{M}$, dissolved in PBS containing $0.1 \%$ DMSO) was placed on the round window membrane. We always performed the surgical procedures for the left ear. The contralateral (right side) cochleae were not treated and used as controls. The same procedure was repeated at $\mathrm{P} 30$ to give the second application of 7,8,3' -THF. At P60, the animals were killed after auditory brainstem response (ABR) thresholds were tested. Details of ABR test methods are given in our previously published work (Ahmad et al., 2007).

Both cochleae were processed and compared in histological analysis to evaluate effects of BDNF small molecules in promoting the survival of SGNs in vivo. Consecutive midmodiolar cochlear resin sections $(5 \mu \mathrm{m}$ in thickness) were cut with a microtome (model HM 335E; Microm). Tissues were fixed by transcardiac perfusion of $4 \%$ paraformaldehyde (PFA) dissolved in the PBS. Cochleae were dissected out and subsequently perfused via the oval window with 2\% PFA and $2.5 \%$ glutaraldehyde in PBS and postfixed at $4^{\circ} \mathrm{C}$ overnight. Decalcification was performed for $72 \mathrm{~h}$ at $4^{\circ} \mathrm{C}$ in $0.35 \mathrm{~m}$ EDTA in PBS, pH 7.4. The cochlear samples were then immersed in $2 \%$ osmium tetroxide for $2 \mathrm{~h}$, followed by gradual dehydration in alcohol of increasing grades, infiltrated, and embedded in epoxy resin. Cochlear sections were stained with toluidine blue and examined with a light microscope.

Electrophysiological recordings. Borosilicate glass capillary pipettes (Sutter Instruments) were pulled on a micropipette puller (P-2000; Sutter Instruments), and the electrodes (with a resistance of 1-3 M $\Omega$ ) were fire polished (MF-830; Narishige) before uses. HEPES-buffered HBSS solution was used as the external bathing solution, which contained the following (in mM): $137 \mathrm{NaCl}, 0.2 \mathrm{Na}_{2} \mathrm{HPO}_{4}, 5.4 \mathrm{KCl}, 0.4 \mathrm{KH}_{2} \mathrm{PO}_{4}, 1$ $\mathrm{MgCl}_{2}, 1.2 \mathrm{CaCl}_{2}$, and $10 \mathrm{HEPES}$. The pipette internal solution contained the following (in mM): $140 \mathrm{KCl}, 2 \mathrm{MgCl}_{2} \cdot 2 \mathrm{H}_{2} \mathrm{O}, 1.2 \mathrm{CaCl}_{2}, 10 \mathrm{EGTA}$, and 10 HEPES, pH buffered to 7.3 with $\mathrm{KOH}$. Coverslips with cultured SGNs were placed in a perfusion chamber mounted on a Carl Zeiss upright fixed-stage microscope (AxioSkop II). The series capacitance was compensated, and a tight seal $(>1 \mathrm{G} \Omega)$ was maintained during recordings. Experiments were controlled by Clampex software (version9.1). Signals from a patch-clamp amplifier were digitized via a Digidata 1322A interface (Axon Axopatch 200B; Molecular Devices). Data were analyzed offline using pClamp (version 9.2; Molecular Devices) and Origin 7.0 (OriginLab) software.

Electrically evoked ABRs (eABRs) were recorded by delivering biphasic rectangular pulses generated from an isolated pulse stimulator (model 2100; A-M Systems) through an electrode placed on the round window membrane. The return electrode was placed in the neck muscle as the reference. These current pulses had alternating polarity to provide charge balancing. The pulses had a width of $80 \mu$ s and an interpulse interval of $10 \mathrm{~ms}$. The amplitude was manually controlled between 50 and $800 \mu \mathrm{A}$. Three recording electrodes were placed subcutaneously at the nose, the right and left mastoid areas to record the eABRs. These signals were amplified and filtered first through a differential amplifier (DAM 70; WPI) and then by a direct current amplifier (LPF 202A; Warner Instruments). The signals were digitized by a Digidata 1322A (Molecular Devices) and recorded using the Clampex 9.2 (Molecular Devices) software package. The first positive peak (P1) in the eABR waveforms was always blocked by the electrical artifact. We therefore used the first negative peak and the second positive peak (wave N1-P2) to measure the threshold of the eABRs, which were defined as the amplitude of stimulus current that evoked a consistently visible N1-P2 waveform (see Fig. 5). N1-P2 amplitudes for all current levels in the experimental and control animals were analyzed using repeated-measures ANOVA, and $t$ tests were used to analyze measurements at suprathreshold current levels.

Quantitative histological data analyses. The cultured spiral ganglia were imaged using a confocal microscope using a $40 \times$ oil-immersion lens (numerical aperture 1.2; Zeiss LSM; Carl Zeiss). The distance between each optical section was $10 \mu \mathrm{m}$. SGNs were specifically immunolabeled with an antibody against $\beta$-tubulin, which labeled both cell body and neuritis (see Figs. 1-4). NIH Image J software (version 1.63) was used for quantitative analysis. Cells were counted in each optical section when the nucleus comprised $>40 \%$ of the soma area. Because SGNs are $\sim 10 \mu \mathrm{m}$ in diameter and optical sections were taken every $10 \mu \mathrm{m}$, this counting procedure greatly reduced the chances of each SGN being double 

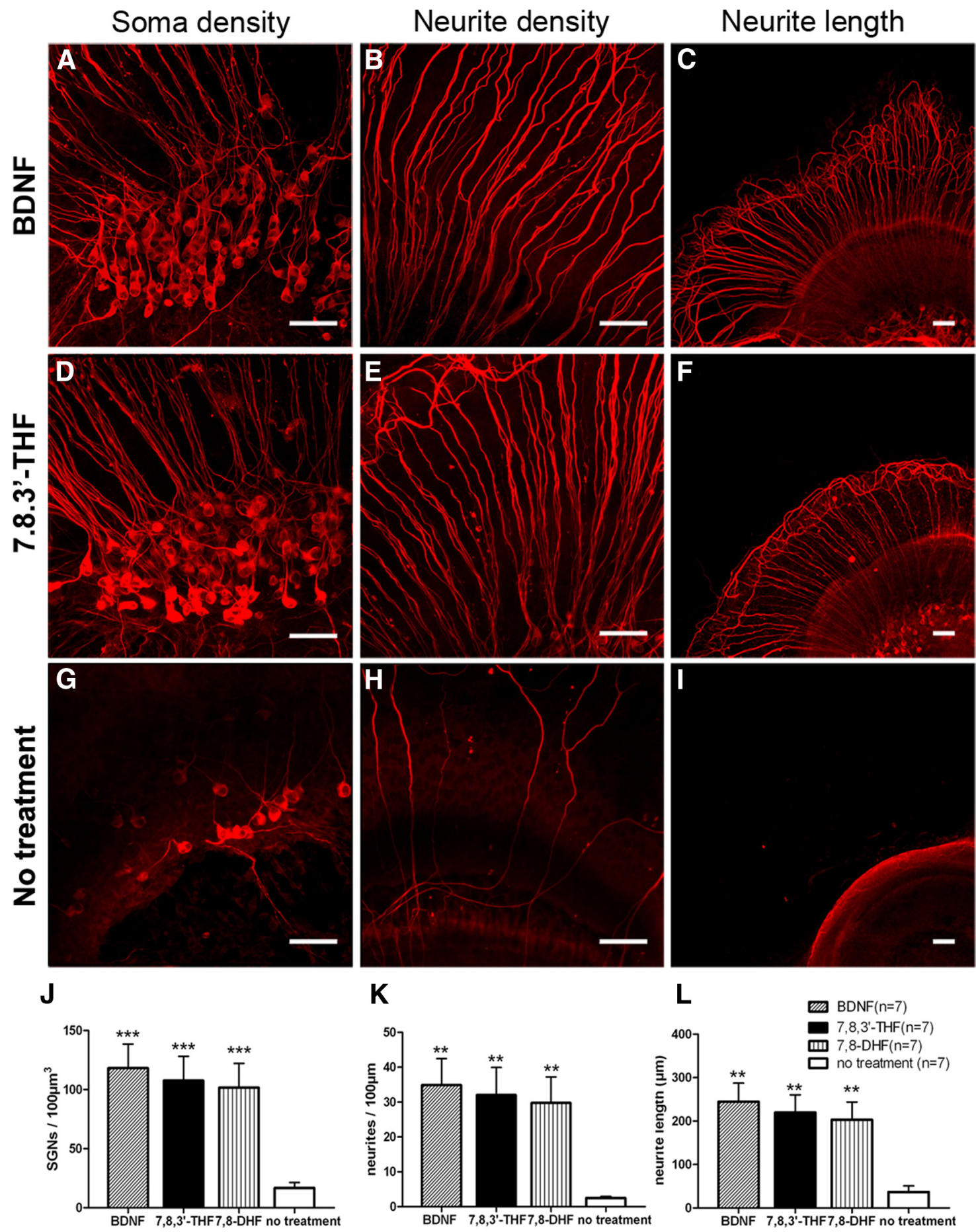

Figure 1. Neuronal protective effect of small-molecule TrkB agonists on SGNs tested in organotypic cochlear cultures. Confocal images of $\beta$-tubulin immunolabeled SGNs maintained in organotypic cochlear cultures for $3 \mathrm{~d}$ treated with BDNF ( $100 \mathrm{ng} / \mathrm{ml} ; \boldsymbol{A}-\boldsymbol{C}), 7,8,3^{\prime}$-THF ( $\left.300 \mathrm{~nm} ; \mathbf{D}-\boldsymbol{F}\right)$, and no supplement $(\mathbf{G}-\boldsymbol{I})$. SGN soma, neurites, and length of neurites are displayed in left $(\boldsymbol{A}$, $\boldsymbol{D}, \boldsymbol{G})$, middle $(\boldsymbol{B}, \boldsymbol{E}, \boldsymbol{H})$, and right $(\boldsymbol{C}, \boldsymbol{F}, \boldsymbol{I})$ columns, respectively. Scale bars, $\sim 50 \mu \mathrm{m}$. Results are quantified for $S G N$ soma densities $(\boldsymbol{J})$, neurite densities $(\boldsymbol{K})$, and the length of neurite outgrowth (L) in BDNF, 7,8,3'-THF, 7,8-DHF, and control groups. ${ }^{* *} p<0.01,{ }^{* * *} p<0.001$, tested by the Student's $t$ test by comparing with corresponding controls (no treatment group). Data are presented as mean \pm SEM.

counted. Neuronal counts from each optical section were summed for all the sections to give the total count of neurons in each explant of cochlea culture. Neuronal density per each $100 \mu \mathrm{m}^{3}$ was subsequently calculated.

SGN density in vivo was quantified from midmodiolar sections of mouse cochleae obtained from P60 old mice. The resin sections were cut in $5 \mu \mathrm{m}$ thickness. Two sections separated by $40 \mu \mathrm{m}$ were used in counting the survived SGNs to minimize the possibility of double counting because the largest soma diameter should be $<20 \mu \mathrm{m}$. A straightforward point-counting method (Leake and Hradek, 1988) was used to estimate SGN density. The number of SGNs in the section was divided by the area of the Rosenthal's canal to obtain the density of SGNs. Counting errors were corrected by using the Abercrombie's equation (Guillery, 2002): $T / T+h$, in which $T$ is the section thickness, and $h$ is the mean diameter of the SGNs. The Student's $t$ test was used to determine the significance of differences between various groups, and a $p$ value of $<0.05$ was used. Both perikaryal area and cell circularity were measured directly in the 
Table 1. Comparison of SG neuron morphology after they were cultured for $3 \mathrm{~d}$ in control condition (defined media without TrkB activation) or with three different TrkB agonists added

\begin{tabular}{|c|c|c|c|c|c|c|c|}
\hline & $\begin{array}{l}\text { Control } \\
\text { (no TrkB activation) }\end{array}$ & $\begin{array}{l}\text { 7,8,3-THF } \\
(300 \mathrm{~nm})\end{array}$ & $\begin{array}{l}\text { 7,8-DHF } \\
(300 \mathrm{~nm})\end{array}$ & $\begin{array}{l}\text { BDNF } \\
(100 \mathrm{ng} / \mathrm{ml})\end{array}$ & $\begin{array}{l}\text { 7,8,3'-THF-treated } \\
\text { cochleae }\end{array}$ & $\begin{array}{l}\text { Untreated } \\
\text { cochleae }\end{array}$ & WT cochleae \\
\hline SGN soma density neurons $/ 100 \mu \mathrm{m}^{3}$ & $17 \pm 5$ & $108 \pm 20$ & $102 \pm 21$ & $118 \pm 20$ & & & \\
\hline Neurite density (per $100 \mu \mathrm{m}$ ) & $3 \pm 0.3$ & $33 \pm 8$ & $30 \pm 7$ & $36 \pm 8$ & & & \\
\hline Length of neurite ( $\mu \mathrm{m})$ & $38 \pm 14$ & $230 \pm 43$ & $213 \pm 41$ & $255 \pm 43$ & & & \\
\hline Soma area of SGN in cochlear sections (basal turn) & & & & & $181 \pm 14$ & $158 \pm 14$ & $190 \pm 9$ \\
\hline Soma area of SGN in cochlear sections (middle turn) & & & & & $174 \pm 14$ & $152 \pm 14$ & $182 \pm 7$ \\
\hline Cell circularity (basal turn) & & & & & $0.85 \pm 0.05$ & $0.76 \pm 0.07$ & $0.88 \pm 0.02$ \\
\hline Cell circularity (middle turn) & & & & & $0.86 \pm 0.07$ & $0.74 \pm 0.08$ & $0.88 \pm 0.01$ \\
\hline
\end{tabular}

$n=7$ for all conditions.
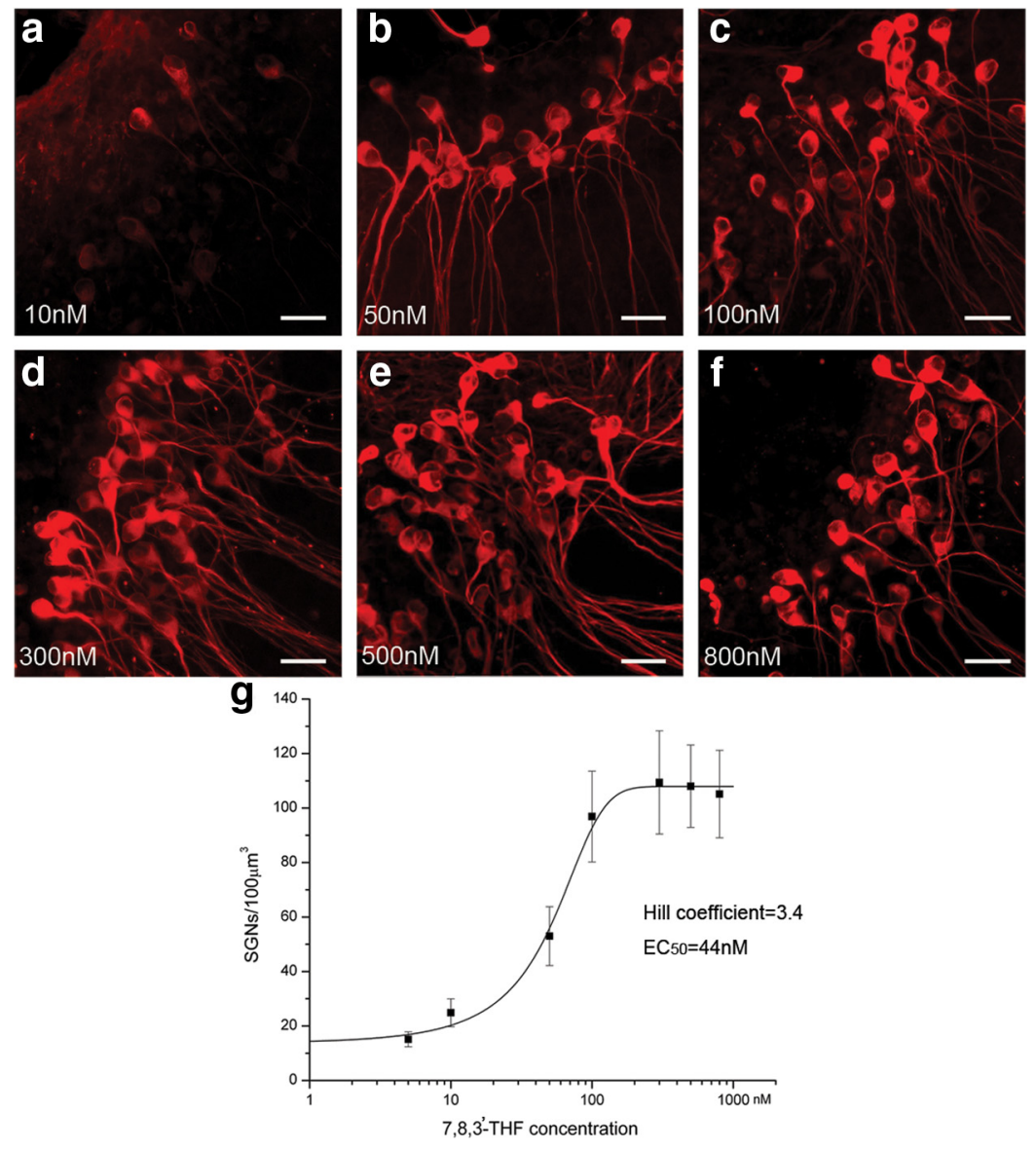

Figure 2. Dose responses of the neuroprotective effect. Confocal images of $\beta$-tubulin immunolabeled SGNs showing survival of SGNs in various concentrations of 7,8, $3^{\prime}$-THF as indicated in $\boldsymbol{a}-\boldsymbol{f}$. Scale bars, $\sim 25 \mu \mathrm{m} . \boldsymbol{g}$, Dose-response measured by fitting the relationship of average soma density of SGNs in various concentrations of 7,8,3'-THF with the standard dose-response formula. We used a Hill coefficient of 3.4 and $\mathrm{EC}_{50}$ of $44 \mathrm{~nm}$ in the fitting. Data points are given as mean $\pm \mathrm{SEM}$.

NIH Image J program after outlining the innermost boundary of the myelin sheath enveloping the perikaryon. Circularity is calculated as: $4 \pi A / L 2$, where $A$ is area, and $L$ is the perimeter. All quantitative analyses were performed in a blind manner by two independent investigators to ensure the consistency of counting. GraphPad Prism 5 (GraphPad Software) and Origin 7.0 (OriginLab) software were used in data analysis. Statistical analyses were performed using either one-way ANOVA with post hoc Tukey's tests or Student's two-tailed unpaired $t$ tests. Data were presented as mean \pm SEM. The level of significance was set at $p<0.05$.

\section{Results}

$7,8,3^{\prime}$-THF and 7,8-DHF greatly promoted the survival of SGNs in organotypic cochlear cultures

The neuroprotective effects of 7,8,3' -THF and 7,8-DHF were first evaluated in vitro in the culture media used in organotypic cul- tures. Hair cells were killed by applying gentamicin (Zheng and Gao, 1996) to eliminate the supply of endogenous NTs. Cultured in a defined media for $3 \mathrm{~d}$, we found that SGN soma density (Fig. $1 A, D, G, J$ ), neurite density (Fig. $1 G, E, H, K$ ), and length (Fig. $1 C, F, I, L)$ were significantly increased in the presence of either $7,8,3^{\prime}$-THF (300 nM) or 7,8-DHF (300 nM) when compared with a control condition when $\operatorname{TrkB}$ receptor was not activated. The detailed comparison data are given in the Table 1 and Figure $2 j-l$, which suggested that the two smallmolecule TrkB agonists exhibited a potency in promoting the in vitro survival of SGNs similar to that of BDNF. In the absence of any TrkB agonists, SGN soma density was $\sim 17$ neurons $/ 100 \mu \mathrm{m}^{3}$ after $3 \mathrm{~d}$ in culture (Fig. 1G,J). Addition of 7,8,3-THF (300 nM) or 7,8-DHF (300 nM) increased the SGN density to $>100$ neurons $/ 100 \mu^{3}$ (Fig. $1 J$, $p<0.001$ ), which was similar to that obtained when $100 \mathrm{ng} / \mathrm{ml} \mathrm{BDNF}$ was added in the culture media (Table 1). The neurite densities (Fig. $1 \mathrm{~K}$ ) of the cochlear explants as well as the neurite lengths (Fig. $1 L$ ) obtained in the presence of either 7,8,3'-THF or 7,8-DHF were also increased to levels similar to those obtained when BDNF was supplemented in the cultured media (Fig. 1; Table 1) and were significantly greater than those obtained when SGNs were cultured in defined medium only $(p<0.01$; Table 1$)$. To test the dose responses, we found that increasing the concentrations of 7,8, $3^{\prime}$-THF gradually increased the number of survived SGNs (Fig. 2). Saturated concentration was found at $\sim 300 \mathrm{~nm}$, and the $\mathrm{EC}_{50}$ was estimated to be $44 \mathrm{~nm}$ (Fig. $2 g$ ). By a similar procedure, we estimated that the $\mathrm{EC}_{50}$ of 7,8-DHF to be $86 \mathrm{nM}$. These results demonstrated high potency of 7,8,3'-THF and 7,8 -DHF in promoting survival of SGN soma and neurites and were consistent with previously reported survival promotional effects by BDNF obtained in organotypic cochlear cultures (Barclay et al., 2011).

NT-3 provides additive support to BDNF in promoting survival of cultured murine SGNs (Hegarty et al., 1997). When the saturating concentrations of BDNF (100 ng/ml) (Liu et al., 2010) or NT-3 (100 ng/ml) (Malgrange et al., 1996) were applied together with 7,8,3'-THF (200 nM) in the organotypic cochlear cultures, only the combination of 7,8,3' - THF and NT-3 provided 

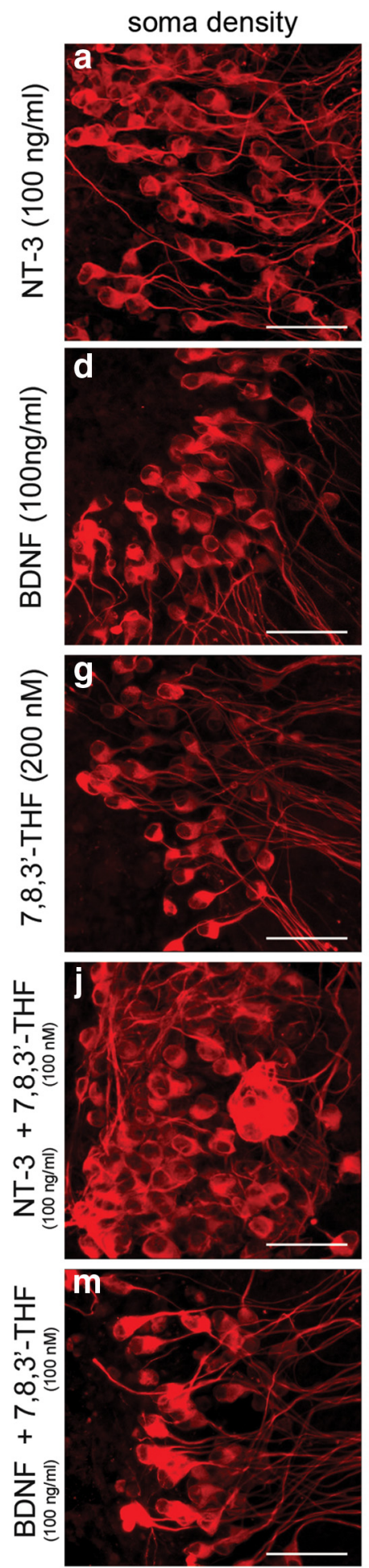

neurite density
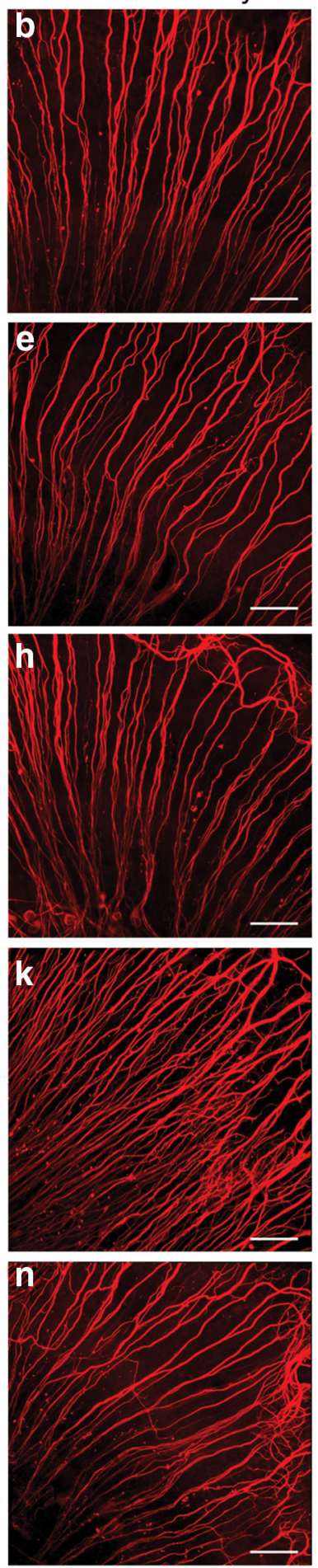

neurite length
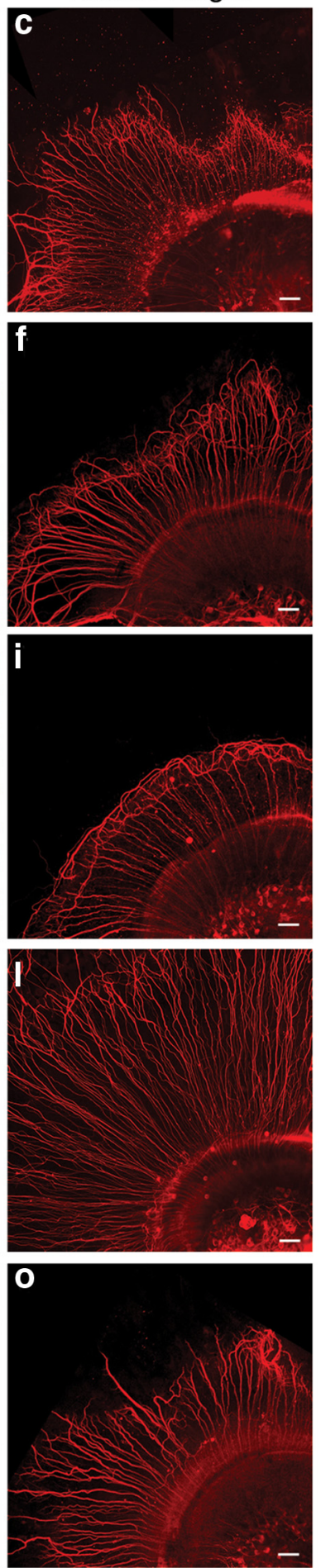
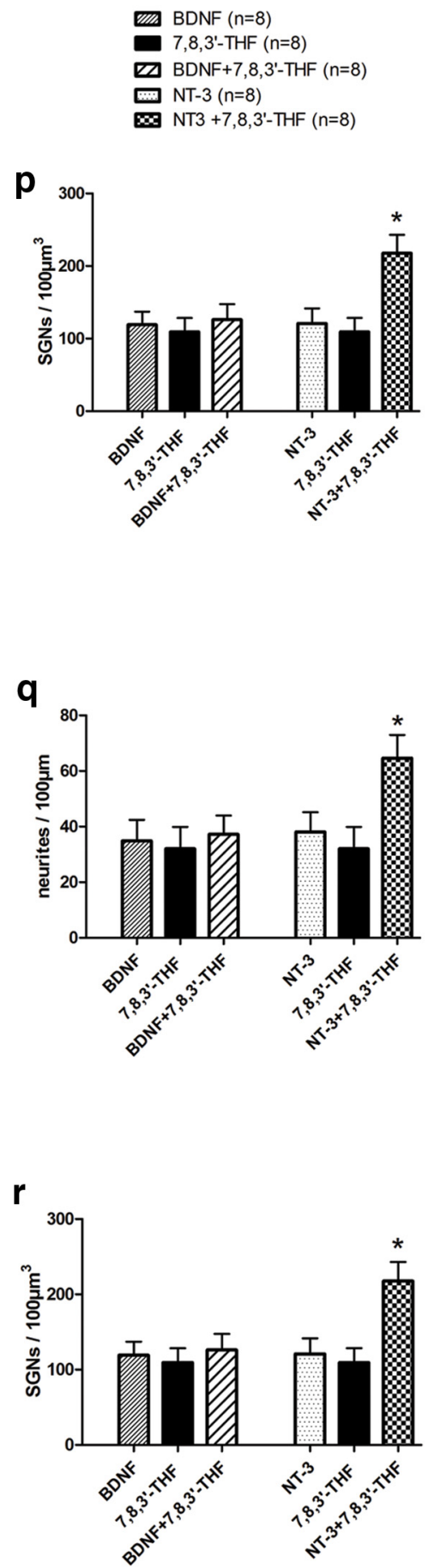

Figure 3. Additive neuroprotective effects of 7,8,3'-THF with NT-3 but not with BDNF tested in organotypic cochlear cultures. Application of NT-3 (a- $\boldsymbol{c})$, BDNF $(\boldsymbol{d}-\boldsymbol{f})$, or 7,8, $3^{\prime}-$ THF $(\boldsymbol{g}-\boldsymbol{i})$ individually in the cultures produced similar increases in SGN soma density and neurite density, as well as neurite outgrowth. Combined applications of $7,8,3^{\prime}-\mathrm{THF}(300 \mathrm{~nm})$ and NT-3 (100 ng/ml; $\left.j-I\right)$ produced greater protection effects for survival of SGNs compared with individual applications of either NT-3 (a-c) or 7,8, $3^{\prime}$-THF $(\boldsymbol{g}-\boldsymbol{i})$. However, combined applications of 7,8,3'-THF and BDNF $(100 \mathrm{ng} / \mathrm{ml})$ did not give additional protection for SGNs $(\boldsymbol{m}-\boldsymbol{0})$. Scale bars, $\sim 50 \mu \mathrm{m}$. $\boldsymbol{p}-\boldsymbol{r}$, Quantitative protective results were compared and given in bar charts for average $S G N$ soma $\operatorname{density}(\boldsymbol{p})$, neurite density $(\boldsymbol{q})$, and length of neurite outgrowth $(\boldsymbol{r}) .{ }^{*} p<0.05$ compared with 7,8,3'-THF or NT-3 applied individually by one-way ANOVA and Tukey's post hoc test. Data are given as mean \pm SEM.

the additive protective effects as measured by SGN density, neurite density, and neurite length (Fig. 3). These results are consistent with the idea that the BDNF small molecules we tested in this study specifically activated the TrkB receptors.
7,8,3'-THF and 7,8-DHF selectively activated TrkB receptors and protected SGNs in a TrkB-dependent manner Binding of BDNF to TrkB triggers its dimerization through conformational changes and induces autophosphorylation of ty- 


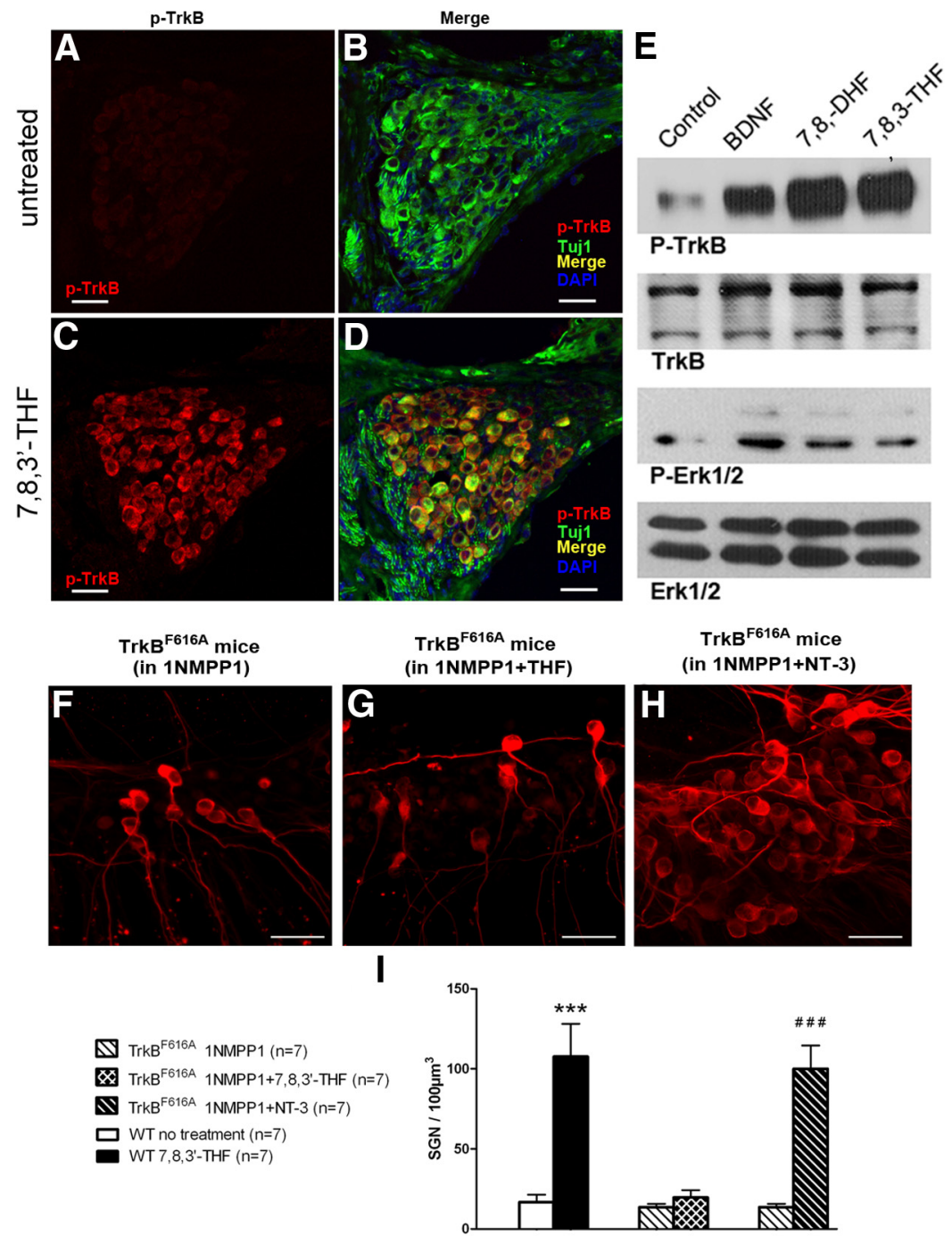

Figure 4. 7,8,3'-THF and 7,8-DHF activated TrkB in SGNs and their neuronal protective effects are TrkB dependent. TrkB tyrosine phosphorylation in the cochlea induced by 7,8,3'-THF and 7,8-DHF was tested by immunolabeling $(\boldsymbol{A}-\boldsymbol{D})$ and Western blot (E). Immunofluorescent staining of cochlear sections with the anti-p-TrkB 816 antibody shows little p-TrkB (red) in SGNs from untreated ears $(\boldsymbol{A}, \boldsymbol{B})$. Strong immunoreactivity of p-TrkB in SGNs was obtained from the contralateral ear in the same animal treated with 7,8, $3^{\prime}$-THF (C, D). Immunoblotting analysis shows 7,8,3'-THF and 7,8-DHF triggered TrkB and Erk1/2 phosphorylation in the cochlear cultures, similar to that caused by adding BDNF and 7,8-DHF (E). Data shown in $\boldsymbol{F}$-I demonstrate that the promotional effect of 7,8, $3^{\prime}$-THF on SGN survival is TrkB dependent. Cochlear cultures of TrkB ${ }^{\mathrm{F} 616 \mathrm{~A}}$ knock-in mice were treated with 1NMPP1 (100 nM) to selectively block TrkB. Whereas TrkB was inactivated, supplements of 7,8,3'-THF showed little neuroprotective effect (comparing $\boldsymbol{F}$ with $\boldsymbol{G}$ ). In a positive control, NT-3 still enhanced SGN survival $(\boldsymbol{H})$. Scale bars, $\sim 50 \mu \mathrm{m}$. Results are quantified in I by counting SGN soma density. ${ }^{* * *} p<0.001$ compared with WT with no exogenous activation of TrkB; ${ }^{\# \# \# p<}$ 0.001 compared with results obtained when TrkB is blocked by 1NMPP1 $(\boldsymbol{F})$. Statistical analyses were performed by Student's $t$ tests. Data are presented as mean \pm SEM.

rosine residues on its intracellular domain, leading to the activation of specific downstream intracellular signaling pathways (Middlemas et al., 1994). Immunofluorescent staining of cochlear sections with an antibody specific to phosphorylated TrkB (Liu et al., 2010) showed that applications of 7,8,3' -THF to the otic bulla yielded a positive immunoreactivity at the applied side of the cochlea, whereas the contralateral untreated cochleae in the same animal was negative (comparing Fig. $4 A-D$ ). Immunoblotting analysis demonstrated that treatments with 7,8,3'-THF, 7,8-DHF, and BDNF (a positive control) significantly increased the phosphorylation of both TrkB and Erk1/2 (Fig. $4 E$ ). In contrast, the total amount of TrkB and Erk1/2 protein remained unchanged (Fig. $4 E$ ). These results indicated that $7,8,3^{\prime}$-THF and 7,8 DHF activated TrkB receptors as well as the downstream MAPK pathway.

A point mutation $\mathrm{F} 616 \mathrm{~A}$ in the TrkB renders it sensitive to the blockage by 1-naphthyl-methyl protein phosphatase 1 (1NMPP1) (Bishop et al., 2000), which was used to null functions of the TrkB in a controlled manner (Chen et al., 2005). To further test whether the neuroprotective effect of 7,8,3'-THF is dependent on the TrkB activation, we used cochleae isolated from TrkB ${ }^{\text {F616A }}$ knock-in mice. Contrary to the dramatic increase of SGN density by the applications of $7,8,3^{\prime}$-THF in cochlear cultures of wild-type (WT) mice (Fig. 1), the protective effects of $7,8,3^{\prime}$-THF were abolished by blockage of $\operatorname{TrkB}$ with 100 nM 1NMPP1 (Fig. 4F-I). As a control test, we found that the survival-promoting effect exerted by the NT-3 through the TrkC receptor was preserved in the presence of 1NMPP1 (Fig. 4H,I) in cochlear cultures dissected from the TrkB ${ }^{\text {F616A }}$ mice. These results further support the idea that 7,8,3'THF selectively activates TrkB in exerting its neuroprotective actions on SGNs.

\section{Survived SGNs show electrical excitability in vitro and in vivo}

The electrical excitability of SGNs was tested in vitro by patch-clamp recordings and in vivo by recording eABRs to assess the neuronal functions after rescue. Transient inward sodium currents were reliably elicited by depolarizing voltages more positive than $-40 \mathrm{mV}$ from a holding potential of $-80 \mathrm{mV}$ in freshly isolated SGNs (Fig. 1A) and from neurons cultured with 7,8,3' -THF for $3 \mathrm{~d}$ (Fig. 5C). However, the average amplitude of the peak sodium currents (measured at +20 $\mathrm{mV}$ ) was substantially larger than that obtained from freshly dissected SGNs $[1003 \pm 89 \mathrm{pA}(n=10)$ compared to $661 \pm 60 \mathrm{pA}(n=10) ; p<0.01$ ] (Fig. $5 E)$. Under the current clamp, a single action potential (AP) was evoked by suprathreshold current stimuli from both freshly dissected and 7,8,3' ${ }^{\prime}$ THF-treated SGNs (Fig. $5 B, D$, respectively). The threshold currents needed to elicit APs were similar under both conditions $[90 \pm 12 \mathrm{pA}(n=10)$ vs $93 \pm 14 \mathrm{pA}(n=10)]$ (Fig. $5 F)$. These data obtained in vitro indicated that SGNs survived in cultures were able to generate robust inward sodium currents to trigger the APs. We also recorded eABR responses to monitor the function of survived SGNs in vivo. Examples of eABR traces recorded from the cochlea of WT animals, cCx26 null mice treated with 7,8-DHF, and their controls (untreated) are described in Figure 5, $G$ and $H$. The threshold stimulus currents needed to evoke the N1-P2 waves were compared among the three groups using a one-way ANOVA with post hoc Tukey's test. Thresholds were significantly lower in 7,8-DHF-treated cCx26 null mice (412 
A

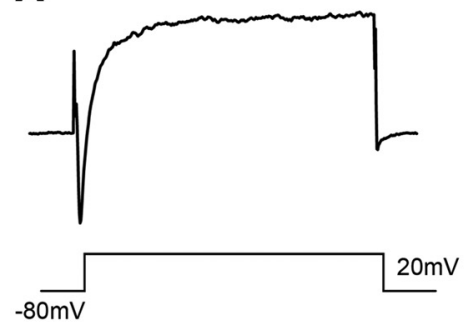

C

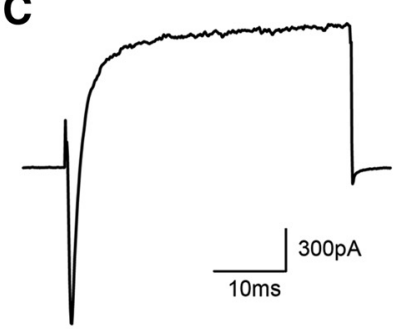

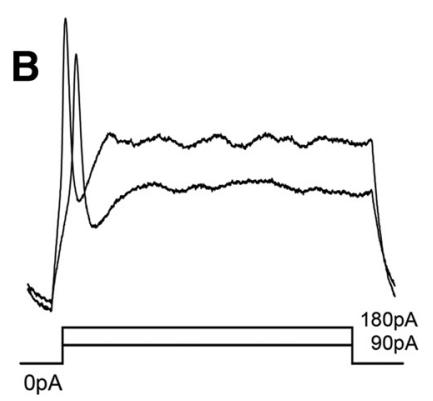

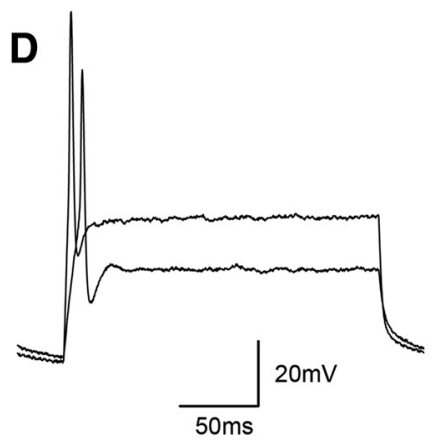

E

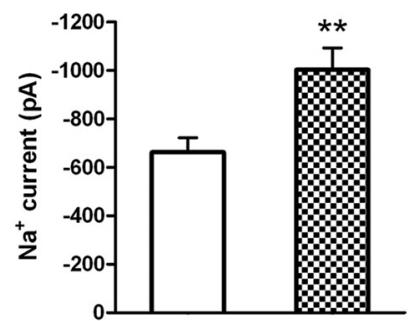

$\mathbf{F}$

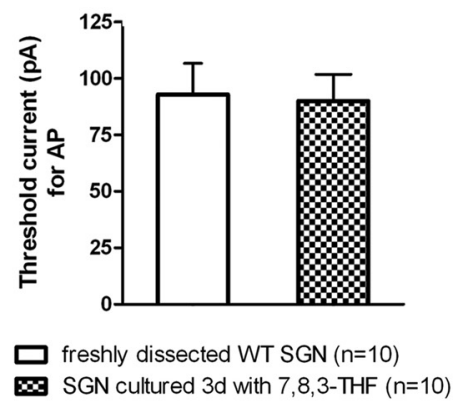

G

WT

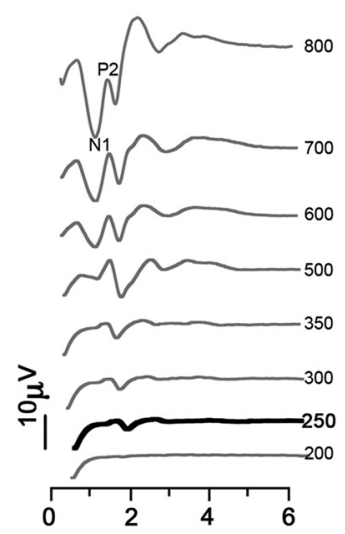

7,8-DHF treated

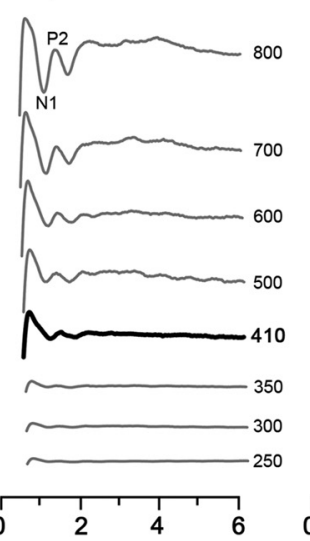

untreated control

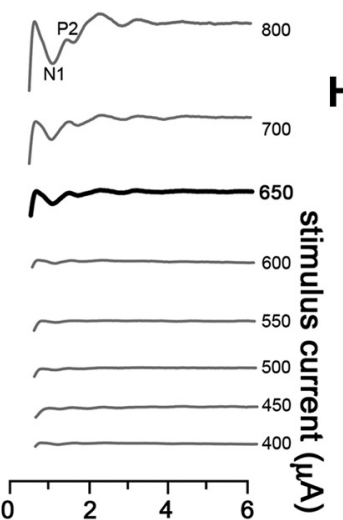

H
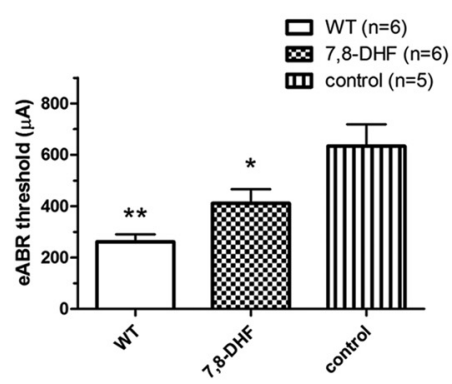

Figure 5. SGNs rescued by 7,8,3'-THF are electrically excitable and give lower thresholds in eABR tests. $A, C$, Currents recorded under whole-cell voltage clamp from SGNs in response to voltage steps. They were recorded from either freshly dissected SGNs ( $\boldsymbol{A})$ or SGNs survived after $3 \mathrm{~d}$ in organotypic cultures in the presence of $7,8,3^{\prime}-\mathrm{THF}(\boldsymbol{C}) \cdot \boldsymbol{B}, \boldsymbol{D}, \mathrm{APs}$ recorded under current clamp from SGNs. These neurons are either freshly dissected $(\boldsymbol{B})$ or cultured for $3 \mathrm{~d}$ in the presence of 7,8,3'-THF (D). $\boldsymbol{E}$, The average amplitude of sodium currents recorded from SGNs cultured with 7,8,3'-THF (filled bar) were substantially greater than those measured from freshly dissected SGNs (blank bar) ${ }^{* *} p<0.01$, determined by Student's $t$ tests). $\boldsymbol{F}$, The average threshold currents needed to elicit APs from SGNs in freshly dissected SGNs (blank bar) and SGNs cultured with 7,8,3'-THF (filled bar) were similar ( $p=0.662$ ). G, eABR waveforms recorded from a WT cochlea (data traces in the left column), a 7,8-DHF-treated c $C \times 26$ knock-out cochlea (middle column) and an untreated c $C \times 26$ knock-out cochlea (right column). Thresholds of wave N1-P2 are indicated by the bold traces. $\boldsymbol{H}$, Averaged eABR thresholds of each group. Note that thresholds were significantly lower in WT and 7,8-DHF-treated cochleae compared with those of untreated cochleae. Bar legends are given in the panel. ${ }^{*} p<0.05,{ }^{* *} p<0.01$ compared with untreated control. Determined by one-way ANOVA with post hoc Tukey's test.

$55 \mu \mathrm{A}, n=5)$ than those observed in untreated cCx26 null mice $(634 \pm 85 \mu \mathrm{A}, n=5)$ (Fig. $5 H$ ). As expected, sound-evoked ABR tests showed that the acoustic hearing in animals was not restored as a result of the loss of hair cells (see Fig. 7a).

\section{Morphological evidence supporting that 7,8,3'-THF and 7,8- DHF protected SGNs from degeneration in $\mathrm{CCx} 26$ null mice} Our previous studies demonstrated that hair cells die rapidly in the middle and basal turns of cCx26 null mice during P14-P21. Most SGNs in the Rosenthal's canal were degenerated by P60, except those in the apical turn (Sun et al., 2009; Wang et al., 2009). Therefore, we used cCx26 null mice to test the in vivo efficacy of 7,8,3'-THF and 7,8-DHF in protecting the SGNs. We applied the compounds only to the left bulla. The contralateral ear was used as an untreated control to compare the protective effects in the same animal. Both cochleae were examined 2 months after birth.

Cochlear sections were examined for the morphological rescue effects. As expected, sections obtained from WT animals demonstrated densely packed SGNs and nerve fibers of all cochlear turns of the Rothenthal's canal (Fig. 6I-L). These results were in sharp contrast to results obtained from untreated cCx26 null mice, in which a substantial loss of SGNs was observed (Fig. $6 A-D$ ), especially in the middle and basal turns (Fig. $6 A, B$, respectively). In the contralateral cochlea of the same animal in which $7,8,3^{\prime}$-THF or 7,8 -DHF was used, we observed that the SGNs were significantly preserved (Fig. 6, compare rows $A-D$, $E-H)$. SGN density was calculated at four different cochlear locations: basal (B), middle (M), middle-apical (A2), and topapical (A1), summarized in Figure $6 M$ and Table 1. Mean values 

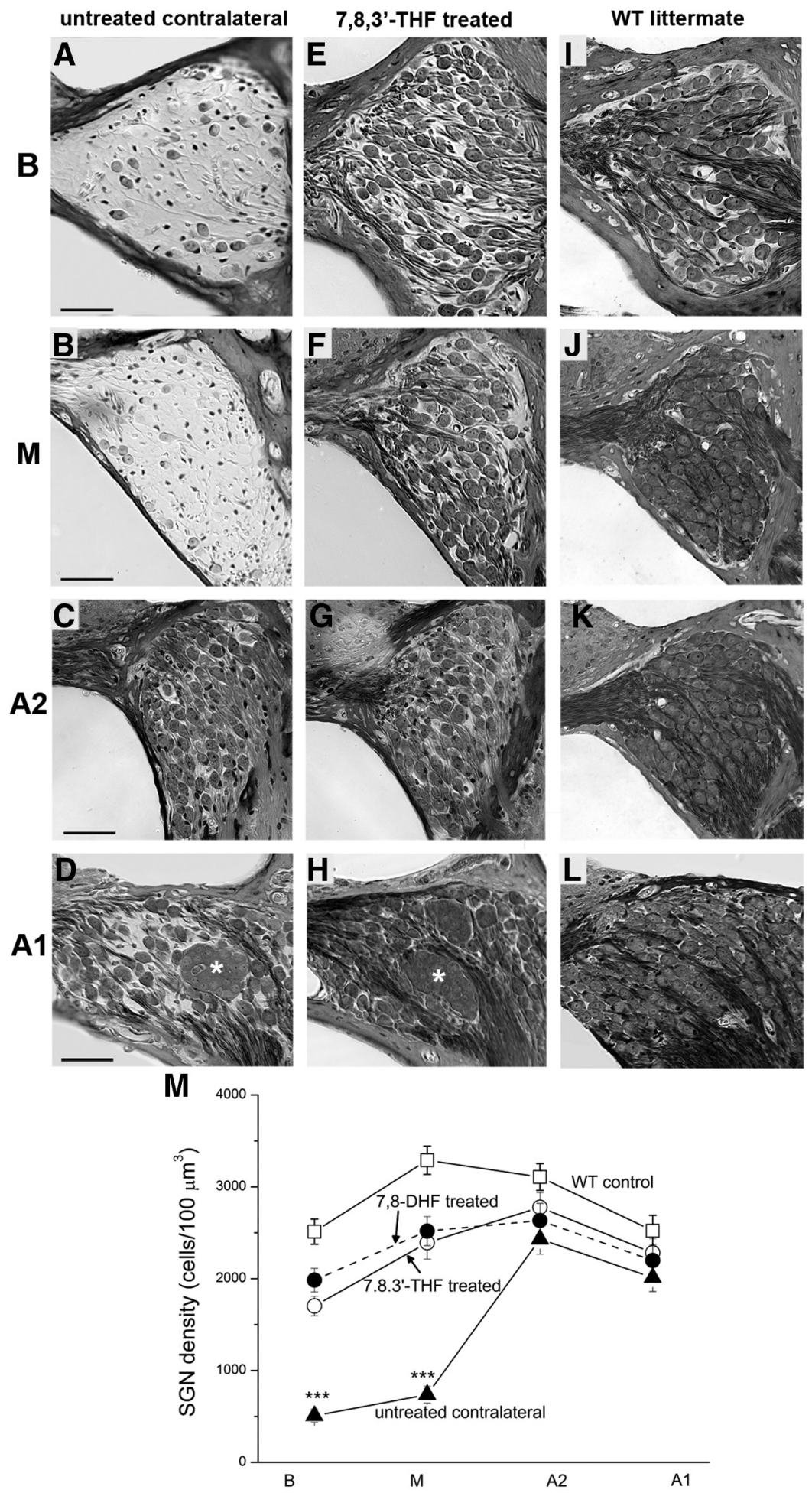

Figure 6. Small-molecule TrkB agonists protected $S G N s$ in the Rosenthal's canal of $C(X 26$ null mice from degeneration. Cochlear sections showing Rosenthal's canal at basal $(B ; A, E, I)$, middle $(M ; B, F, J)$, middle-apical $(A 2 ; C, G, K)$, and top-apical $(A 1 ; D, H, L)$ of untreated $(\boldsymbol{A}-\boldsymbol{D})$ and contralateral treated $(\boldsymbol{E}-\boldsymbol{H})$ cochlea in the same animal. Cochlear sections obtained from WT mice from the same littermate are presented as controls $(\boldsymbol{I}-\boldsymbol{L})$. Asterisks in $\boldsymbol{D}$ and $\boldsymbol{H}$ indicate examples of SGNs clustered together in the apical turn of $\mathrm{c}(\mathrm{X} 26$ null cochleae. Scale bars, $\sim 50 \mu \mathrm{m}$. Data given in $\boldsymbol{M}$ are quantitative analyses of the mean SGN densities among the untreated, 7,8,3'-THF-treated, 7,8-DHF-treated, and WT mice obtained at four cochlear locations (B, M, A2, and A1). ${ }^{* * *} p<0.001$ compared with all three other groups by two-way ANOVA. Data are given as mean \pm SEM.

of the SGN soma area and cell circularity at the location basal and middle locations were also examined. Soma size and cell circularity of SGNs at basal and middle turns in untreated cCx26 null cochleae were significantly reduced ( $p<0.01$; Table 1$)$. In com- parison, 7,8,3'-THF treatment increased the soma size and cell circularity to approximately the same level as that of normal cochleae (Fig. $7 b, c$, dashed lines).

\section{Discussion}

NTs regulate the development and maintain the survival of neurons in the PNS and CNS (Lewin and Barde, 1996). In the auditory system, most cases of sensorineural hearing loss are caused by loss of hair cells in the cochlea (Dallos et al., 1996; Hudspeth, 1997). The hair cells and surrounding supporting cells are also the primary sources of neurotrophic support for the SGNs (Ylikoski et al., 1993; Schecterson and Bothwell, 1994; Rubel and Fritzsch, 2002) . Death of hair cells usually triggers secondary degeneration of SGNs, starting with the loss of synaptic terminals followed by the disintegration of cell bodies, although the severity and time course of this process may vary among different species and animal models (Pan et al., 2011; Shibata et al., 2011). Depending on the species, the degeneration time course ranges from a few weeks to years (Otte et al., 1978; Leake and Hradek, 1988; Jyung et al., 1989), which results in $>80 \%$ loss of SGNs in a few weeks in many animal models deafened by ototoxic drugs to selectively kill hair cells (Leake and Hradek, 1988; Hardie and Shepherd, 1999; Dodson and Mohuiddin, 2000). It is also realized that degeneration of SGNs in humans is not correlated with the loss of hair cells and the time courses of degeneration are variable among different species (Leake and Hradek, 1988; Dodson and Mohuiddin, 2000; Linthicum and Fayad, 2009). The molecular mechanisms for the differences in the survival of SGNs in different species are unclear. Sources of NTs in the absence of hair cells, such as neurons in the cochlear nuclei (Maricich et al., 2009) or remaining supporting cells (Sugawara et al., 2005), have been suspected.

SGNs transmit sound signals transduced by hair cells to the cochlear nuclei in the brainstem. Substantial loss of SGNs has at least two clinical implications. (1) In the absence of hair cells, the cochlear implant is the most effective treatment for deafness. The device directly stimulates SGNs by applying extracellular field potential with coded patterns of electrical pulses. Large reductions in the number of surviving SGNs below a functioning threshold reduce the benefit of cochlear implants, resulting in poor performance in patients (Clopton et al., 1980; Incesulu and Nadol, 1998; Skinner et al., 2002). (2) Degeneration of significant amounts of SGNs diminishes the hope for developing future treatments based on 
the regeneration of hair cells. Exogenous application of NTs rescues SGNs from degeneration resulting from the loss of cochlear hair cells (Ernfors et al., 1996; Staecker et al., 1996, 1998; Shinohara et al., 2002; Gillespie and Shepherd, 2005; Rejali et al., 2007). These encouraging results have stimulated enormous interest in translational research aimed at applying exogenous NTs to promote the survival of residual SGNs in the cochlea of patients with severe sensorineural hearing loss (Shinohara et al., 2002; Gillespie and Shepherd, 2005; Pettingill et al., 2007; Shepherd et al., 2008). However, none of these studies have advanced to clinical trials, now 16 years after the first series of papers were published (Ernfors et al., 1996; Miller et al., 1997). Because neuroprotective effects depend on the continuous presence of the BDNF (Gillespie et al., 2003), how to prevent proteolytic breakdown of NTs to achieve long-term, recurring, and safe deliveries at desired dosages has been one of the major hurdles hindering the clinical translation (Pettingill et al., 2007). The outcomes of several clinical trials using recombinant BDNF are disappointing (Ochs et al., 2000). Presumably, this is attributable to poor delivery and the short in vivo half-life of BDNF (Thoenen and Sendtner, 2002).

In this study, we provide several pieces of evidence demonstrating that 7,8-DHF and its derivative $7,8,3^{\prime}$-THF strongly activate TrkB receptors in SGNs in drug-treated ears. Both compounds promoted SGN survival and neurite growth in organotypic cultures in a dosedependent manner (Fig. 2). Notably, 7,8,3'-THF displayed a low $\mathrm{EC}_{50}$ of $\sim 44 \mathrm{nM}$. In our published studies (Jang et al., 2010; Liu et al., 2010), we have clearly defined that 7,8-DHF does not activate TrkC. In addition, we also showed that blocking TrkB in $\operatorname{TrkB}^{\mathrm{F} 616 \mathrm{~A}}$ knock-in mice (Chen et al., 2005) with 1NMPP1 antagonized the physiological actions of 7,8-DHF, supporting that TrkB receptor activation by 7,8 -DHF accounts for its specific effect. In this study, the compound also demonstrated additive effects in promoting the SGN survival, as measured by both soma and neurite densities, as well as neurite growth in the presence of NT-3. In contrast, when combined with BDNF, no extra beneficial activity was observed (Fig. 3). These data strongly support the idea that the small molecules tested here mimic the biological functions of BDNF and display additive activity as revealed by NT-3 and BDNF combination. Moreover, we showed that the survived SGNs were functional both in vitro and in vivo (Figs. 4, 5 ), indicating that the compounds not only promoted the neuronal survival but also maintained physiological functions of SGNs. In addition to the prominent efficacy in promoting SGN survival in vitro, we also observed that both 7,8,3'-THF and 7,8-DHF significantly elevated the SGN numbers in the Rosenthal's canal of cCx26 null mice compared with untreated contralateral cochlea (Fig. 6). Hence, these results support the idea that the novel small-molecule BDNF mimetics act as a potent TrkB agonist and provokes TrkB receptor activation in SGNs, as well as strongly enhance SGN survival in a mouse model of human con- genital deafness. The differential rescue results we observed for the SGNs, namely more effective in the basal and middle turns and apparently less profound in the apex, are not reflections of the differential effects of the compounds we used but rather distinctive characters of the mouse model we used. The pattern of degeneration of SGNs in the $\mathrm{cCx} 26 \mathrm{KO}$ mice is always more severe in the middle and basal turns but very minor in the apical turn (Sun et al., 2009; Wang et al., 2009). Interestingly, some of the other genetically modified mice also show a similar pattern of degeneration of SGNs (Pan et al., 2011; Shibata et al., 2011). Remarkably, the SGN survival-promoting effect was completely dependent on the TrkB receptors (Fig. 4). This was demonstrated by the blockage of the TrkB ${ }^{\mathrm{F} 616 \mathrm{~A}}$ with 1 NMPP1, which abolished the neurotrophic activities. In contrast, NT-3 remained active in promoting the SGN neuron survival (Fig. $4 H, I$ ), underscoring the fact that $7,8,3^{\prime}$-THF specifically exerted its neurotrophic action through TrkB receptors.

Our previous in vitro studies indicate that 7,8-DHF binds to the purified TrkB recombinant extracellular domain (ECD) in a 1:1 ratio, indicating that one molecule of TrkB receptor contains one 7,8-DHF ligand binding site (Jang et al., 2010). Recently, using a molecular modeling approach, we show that $7,8-\mathrm{DHF}$ is inserted into a large cavity on the back of the leucine-rich repeat of the TrkB ECD (Liu et al., 2012). In this study, the Hill coefficient suggested that $7,8,3^{\prime}$-THF had a positive cooperativity in provoking spiral ganglion survival. Conceivably, these two small molecules share the same binding site on TrkB receptor. On the plasma membrane of the neurons, the active TrkB receptors exhibit as dimer on the ligand binding on each receptor. However, 
it remains unclear whether multiple receptor complexes occur on SGNs on 7,8,3'-THF stimulation. Dosage responses of our neuronal survival data suggest that additional in-depth investigation regarding the biophysical association between the small molecules and downstream activation of the TrkB receptor is needed. Presumably, other unknown binding targets also allosterically affect the ligand interaction with the TrkB receptor to yield the positive cooperativity we observed here.

Both 7,8-DHF and 7,8,3'-THF are flavonoid derivatives. They contain multiple hydroxy groups on the benzene rings. Because phenol or catechol groups are prone to be metabolized by glucuronidation, sulfation, and methylation in the liver or plasma, they usually possess relatively short half-lives in the circulation system, leading to poor oral bioavailability. However, for the purposes of this study, the compounds were applied locally to avoid the delivery problem in the systematic administration and to give us the ability to compare survival of SGNs between the two ears in the same animal. We used a small cube of an absorbable gelatin sponge soaked with 7,8,3'-THF on the round window membrane to deliver the drug. Conceivably, 7,8,3'-THF may be administrated topically by dropping the drug solution into the middle ear cavity of impaired ears. The cochlear implant is currently the only effective therapeutic treatment for patients suffering from severe sensorineural deafness. This device provides auditory cues by directly stimulating SGNs, thus bypassing the damaged or missing hair cells. The survival of SGNs in the cochlea is critical for the optimal performance of cochlear implants (Clopton et al., 1980; Incesulu and Nadol, 1998). Previous studies revealed that 7,8DHF has no detectable toxicities, even when given at high dosages in animal studies (Payá et al., 1993; Tasdemir et al., 2006), suggesting that it has negligible systemic side effects. A number of recent studies using 7,8-DHF have shown promising therapeutic effects for numerous neurological diseases (Choi et al., 2010; Liu et al., 2010; Johnson et al., 2012; Devi and Ohno, 2012). Studies show that 7,8-DHF fully mimics BDNF and exhibits promising therapeutic effects in animal models of depression (Blugeot et al., 2011), Alzheimer's disease (Devi and Ohno, 2012), and Rett syndrome (Johnson et al., 2012). Compared with intracochlear infusion of BDNF, the local or systematic application of 7,8-DHF or 7,8,3' -THF should also be advantageous in terms of better pharmacokinetic properties than those observed with polypeptides. Conceivably, the identification of the promising small-molecule compounds (7,8,3'-THF and 7,8-DHF) has brought us one step closer to the effective translation of basic bench-top research of neuroprotection of SGNs into bedside clinical practice.

\section{References}

Ahmad S, Tang W, Chang Q, Qu Y, Hibshman J, Li Y, Söhl G, Willecke K, Chen P, Lin X (2007) Restoration of connexin26 protein level in the cochlea completely rescues hearing in a mouse model of human connexin30-linked deafness. Proc Natl Acad Sci U S A 104:1337-1341. CrossRef Medline

Barclay M, Ryan AF, Housley GD (2011) Type I vs type II spiral ganglion neurons exhibit differential survival and neuritogenesis during cochlear development. Neural Dev 6:33-48. CrossRef Medline

Bishop AC, Ubersax JA, Petsch DT, Matheos DP, Gray NS, Blethrow J, Shimizu E, Tsien JZ, Schultz PG, Rose MD, Wood JL, Morgan DO, Shokat KM (2000) A chemical switch for inhibitor-sensitive alleles of any protein kinase. Nature 407:395-401. CrossRef Medline

Blugeot A, Rivat C, Bouvier E, Molet J, Mouchard A, Zeau B, Bernard C, Benoliel JJ, Becker C (2011) Vulnerability to depression: from brain neuroplasticity to identification of biomarkers. J Neurosci 31:1288912899. CrossRef Medline

Chang Q, Tang W, Ahmad S, Zhou B, Lin X (2008) Gap junction mediated intercellular metabolite transfer in the cochlea is compromised in connexin30 null mice. PLoS One 3:e4088. CrossRef Medline
Chen X, Ye H, Kuruvilla R, Ramanan N, Scangos KW, Zhang C, Johnson NM, England PM, Shokat KM, Ginty DD (2005) A chemical-genetic approach to studying neurotrophin signaling. Neuron 46:13-21. CrossRef Medline

Choi DC, Maguschak KA, Ye K, Jang SW, Myers KM, Ressler KJ (2010) Prelimbic cortical BDNF is required for memory of learned fear but not extinction or innate fear. Proc Natl Acad Sci U S A 107:2675-2680. CrossRef Medline

Clopton BM, Spelman FA, Miller JM (1980) Estimates of essential neural elements for stimulation through a cochlear prosthesis. Ann Otol Rhinol Laryngol Suppl 89:5-7. Medline

Dallos P, Popper AN, Fay RR (1996) Springer handbook of auditory research: the cochlea. New York: Springer.

Devi L, Ohno M (2012) 7,8-Dihydroxyflavone, a small-molecule TrkB agonist, reverses memory deficits and BACE1 elevation in a mouse model of Alzheimer's disease. Neuropsychopharmacology 37:434-444. CrossRef Medline

Dodson HC, Mohuiddin A (2000) Response of spiral ganglion neurones to cochlear hair cell destruction in the guinea pig. J Neurocytol 29:525-537. CrossRef Medline

Ernfors P, Van De Water T, Loring J, Jaenisch R (1995) Complementary roles of BDNF and NT-3 in vestibular and auditory development. Neuron 14:1153-1164. CrossRef Medline

Ernfors P, Duan ML, ElShamy WM, Canlon B (1996) Protection of auditory neurons from aminoglycoside toxicity by neurotrophin-3. Nat Med 2:463-467. CrossRef Medline

Fariñas I, Jones KR, Backus C, Wang XY, Reichardt LF (1994) Severe sensory and sympathetic deficits in mice lacking neurotrophin-3. Nature 369:658-661. CrossRef Medline

Fritzsch B, Pirvola U, Ylikoski J (1999) Making and breaking the innervation of the ear: neurotrophic support during ear development and its clinical implications. Cell Tissue Res 295:369-382. CrossRef Medline

Gillespie LN, Shepherd RK (2005) Clinical application of neurotrophic factors: the potential for primary auditory neuron protection. Eur J Neurosci 22:2123-2133. CrossRef Medline

Gillespie LN, Clark GM, Bartlett PF, Marzella PL (2003) BDNF-induced survival of auditory neurons in vivo: cessation of treatment leads to accelerated loss of survival effects. J Neurosci Res 71:785-790. CrossRef Medline

Guillery RW (2002) On counting and counting errors. J Comp Neurol 447: 1-7. CrossRef Medline

Hardie NA, Shepherd RK (1999) Sensorineural hearing loss during development: morphological and physiological response of the cochlea and auditory brainstem. Hear Res 128:147-165. CrossRef Medline

Hegarty JL, Kay AR, Green SH (1997) Trophic support of cultured spiral ganglion neurons by depolarization exceeds and is additive with that by neurotrophins or cAMP and requires elevation of $\left[\mathrm{Ca}^{2+}\right]_{i}$ within a set range. J Neurosci 17:1959-1970. Medline

Hudspeth AJ (1997) How hearing happens. Neuron 19:947-950. CrossRef Medline

Incesulu A, Nadol JB Jr (1998) Correlation of acoustic threshold measures and spiral ganglion cell survival in severe to profound sensorineural hearing loss: implications for cochlear implantation. Ann Otol Rhinol Laryngol 107:906-911. Medline

Jang SW, Liu X, Yepes M, Shepherd KR, Miller GW, Liu Y, Wilson WD, Xiao G, Blanchi B, Sun YE, Ye K (2010) A selective TrkB agonist with potent neurotrophic activities by 7,8-dihydroxyflavone. Proc Natl Acad Sci U S A 107:2687-2692. CrossRef Medline

Johnson RA, Lam M, Punzo AM, Li H, Lin BR, Ye K, Mitchell GS, Chang Q (2012) 7,8-dihydroxyflavone (7,8-DHF) exhibits therapeutic efficacy in a mouse model of Rett syndrome. J Appl Physiol 112:704-710. Medline

Jyung RW, Miller JM, Cannon SC (1989) Evaluation of eighth nerve integrity by the electrically evoked middle latency response. Otolaryngol Head Neck Surg 101:670-682. Medline

Kawamoto K, Oh SH, Kanzaki S, Brown N, Raphael Y (2001) The functional and structural outcome of inner ear gene transfer via the vestibular and cochlear fluids in mice. Mol Ther 4:575-585. CrossRef Medline

Leake PA, Hradek GT (1988) Cochlear pathology of long term neomycin induced deafness in cats. Hear Res 33:11-33. CrossRef Medline

Lefebvre PP, Malgrange B, Staecker H, Moghadass M, Van de Water TR, Moonen G (1994) Neurotrophins affect survival and neuritogenesis by 
adult injured auditory neurons in vitro. Neuroreport 5:865-868. CrossRef Medline

Lewin GR, Barde YA (1996) Physiology of the neurotrophins. Annu Rev Neurosci 19:289-317. CrossRef Medline

Linthicum FH Jr, Fayad JN (2009) Spiral ganglion cell loss is unrelated to segmental cochlear sensory system degeneration in humans. Otol Neurotol 30:418-422. CrossRef Medline

Liu X, Chan CB, Jang SW, Pradoldej S, Huang J, He K, Phun LH, France S, Xiao G, Jia Y, Luo HR, Ye K (2010) A synthetic 7,8-dihydroxyflavone derivative promotes neurogenesis and exhibits potent antidepressant effect. J Med Chem 53:8274-8286. CrossRef Medline

Liu X, Chan CB, Qi Q, Xiao G, Luo HR, He X, Ye K (2012) Optimization of a small tropomyosin-related kinase B (TrkB) agonist 7,8-dihydroxyflavone active in mouse models of depression. J Med Chem 55:8524-8537. CrossRef Medline

Malgrange B, Lefebvre P, Van de Water TR, Staecker H, Moonen G (1996) Effects of neurotrophins on early auditory neurones in cell culture. Neuroreport 7:913-917. CrossRef Medline

Maricich SM, Xia A, Mathes EL, Wang VY, Oghalai JS, Fritzsch B, Zoghbi HY (2009) Atoh1-lineal neurons are required for hearing and for the survival of neurons in the spiral ganglion and brainstem accessory auditory nuclei. J Neurosci 29:11123-11133. CrossRef Medline

Middlemas DS, Meisenhelder J, Hunter T (1994) Identification of TrkB autophosphorylation sites and evidence that phospholipase C-gamma 1 is a substrate of the TrkB receptor. J Biol Chem 269:5458-5466. Medline

Miller JM, Chi DH, O’Keeffe LJ, Kruszka P, Raphael Y, Altschuler RA (1997) Neurotrophins can enhance spiral ganglion cell survival after inner hair cell loss. Int J Dev Neurosci 15:631-643. CrossRef Medline

Ochs G, Penn RD, York M, Giess R, Beck M, Tonn J, Haigh J, Malta E, Traub M, Sendtner M, Toyka KV (2000) A phase I/II trial of recombinant methionyl human brain derived neurotrophic factor administered by intrathecal infusion to patients with amyotrophic lateral sclerosis. Amyotroph Lateral Scler Other Motor Neuron Disord 1:201-206. CrossRef Medline

Otte J, Schunknecht HF, Kerr AG (1978) Ganglion cell populations in normal and pathological human cochleae. Implications for cochlear implantation. Laryngoscope 88:1231-1246. CrossRef Medline

Pan N, Jahan I, Kersigo J, Kopecky B, Santi P, Johnson S, Schmitz H, Fritzsch B (2011) Conditional deletion of Atoh1 using Pax2-Cre results in viable mice without differentiated cochlear hair cells that have lost most of the organ of Corti. Hear Res 275:66-80. CrossRef Medline

Payá M, Ferrandiz ML, Sanz MJ, Alcaraz MJ (1993) Effects of phenolic compounds on bromobenzene-mediated hepatotoxicity in mice. Xenobiotica 23:327-333. CrossRef Medline

Pettingill LN, Richardson RT, Wise AK, O'Leary SJ, Shepherd RK (2007) Neurotrophic factors and neural prostheses: potential clinical applications based upon findings in the auditory system. IEEE Trans Biomed Eng 54:1138-1148. CrossRef Medline

Rejali D, Lee VA, Abrashkin KA, Humayun N, Swiderski DL, Raphael Y (2007) Cochlear implants and ex vivo BDNF gene therapy protect spiral ganglion neurons. Hear Res 228:180-187. CrossRef Medline

Rubel EW, Fritzsch B (2002) Auditory system development: primary auditory neurons and their targets. Annu Rev Neurosci 25:51-101. CrossRef Medline

Saragovi HU, Gehring K (2000) Development of pharmacological agents for targeting neurotrophins and their receptors. Trends Pharmacol Sci 21:93-98. CrossRef Medline

Schecterson LC, Bothwell M (1994) Neurotrophin and neurotrophin recep- tor mRNA expression in developing inner ear. Hear Res 73:92-100. CrossRef Medline

Shepherd RK, Coco A, Epp SB (2008) Neurotrophins and electrical stimulation for protection and repair of spiral ganglion neurons following sensorineural hearing loss. Hear Res 242:100-109. CrossRef Medline

Shibata SB, Budenz CL, Bowling SA, Pfingst BE, Raphael Y (2011) Nerve maintenance and regeneration in the damaged cochlea. Hear Res 281:5664. CrossRef Medline

Shinohara T, Bredberg G, Ulfendahl M, Pyykkö I, Olivius NP, Kaksonen R, Lindström B, Altschuler R, Miller JM (2002) Neurotrophic factor intervention restores auditory function in deafened animals. Proc Natl Acad Sci U S A 99:1657-1660. CrossRef Medline

Skinner MW, Ketten DR, Holden LK, Harding GW, Smith PG, Gates GA, Neely JG, Kletzker GR, Brunsden B, Blocker B (2002) CT-derived estimation of cochlear morphology and electrode array position in relation to word recognition in Nucleus-22 recipients. J Assoc Res Otolaryngol 3:332-350. CrossRef Medline

Staecker H, Kopke R, Malgrange B, Lefebvre P, Van de Water TR (1996) NT-3 and/or BDNF therapy prevents loss of auditory neurons following loss of hair cells. Neuroreport 7:889-894. CrossRef Medline

Staecker H, Gabaizadeh R, Federoff H, Van De Water TR (1998) Brainderived neurotrophic factor gene therapy prevents spiral ganglion degeneration after hair cell loss. Otolaryngol Head Neck Surg 119:7-13. CrossRef Medline

Sugawara M, Corfas G, Liberman MC (2005) Influence of supporting cells on neuronal degeneration after hair cell loss. J Assoc Res Otolaryngol 6:136-147. CrossRef Medline

Sun J, Ahmad S, Chen S, Tang W, Zhang Y, Chen P, Lin X (2005) Cochlear gap junctions coassembled from Cx26 and 30 show faster intercellular $\mathrm{Ca}^{2+}$ signaling than homomeric counterparts. Am J Physiol Cell Physiol 288:C613-C623. CrossRef Medline

Sun Y, Tang W, Chang Q, Wang Y, Kong W, Lin X (2009) Connexin30 null and conditional connexin 26 null mice display distinct pattern and time course of cellular degeneration in the cochlea. J Comp Neurol 516:569-579. CrossRef Medline

Tasdemir D, Kaiser M, Brun R, Yardley V, Schmidt TJ, Tosun F, Rüedi P (2006) Antitrypanosomal and antileishmanial activities of flavonoids and their analogues: in vitro, in vivo, structure-activity relationship, and quantitative structure-activity relationship studies. Antimicrob Agents Chemother 50:1352-1364. CrossRef Medline

Thoenen H, Sendtner M (2002) Neurotrophins: from enthusiastic expectations through sobering experiences to rational therapeutic approaches. Nat Neurosci [Suppl] 5:1046-1050. CrossRef Medline

Wang Y, Chang Q, Tang W, Sun Y, Zhou B, Li H, Lin X (2009) Targeted connexin26 ablation arrests postnatal development of the organ of Corti. Biochem Biophys Res Commun 385:33-37. CrossRef Medline

Ylikoski J, Pirvola U, Moshnyakov M, Palgi J, Arumäe U, Saarma M (1993) Expression patterns of neurotrophin and their receptor mRNAs in the rat inner ear. Hear Res 65:69-78. CrossRef Medline

Yu Q, Chang Q, Liu X, Gong S, Ye K, Lin X (2012) 7,8,3'-Trihydroxyflavone, a potent small molecule TrkB receptor agonist, protects spiral ganglion neurons from degeneration both in vitro and in vivo. Biochem Biophys Res Commun 422:387-392. CrossRef Medline

Zheng JL, Gao WQ (1996) Differential damage to auditory neurons and hair cells by ototoxins and neuroprotection by specific neurotrophins in rat cochlear organotypic cultures. Eur J Neurosci 8:1897-1905. CrossRef Medline 